\title{
Language, Literacy, and Multiliteracies: Preparing Graduate Students to Provide Language Intervention in the 21st Century
}

\author{
Wanda M. V. Kent \\ Eastern Michigan University, wkent2@emich.edu \\ DOI: doi.org/10.30707/TLCSD2.2Kent
}

Follow this and additional works at: https://ir.library.illinoisstate.edu/tlcsd

Part of the Communication Sciences and Disorders Commons, and the Higher Education Commons

\section{Recommended Citation}

Kent, Wanda M. V. (2018) "Language, Literacy, and Multiliteracies: Preparing Graduate Students to Provide Language Intervention in the 21st Century," Teaching and Learning in Communication Sciences \& Disorders: Vol. 2: Iss. 2, Article 4. DOI: doi.org/10.30707/TLCSD2.2Kent Available at: https://ir.library.illinoisstate.edu/tlcsd/vol2/iss2/4

This Reflection on SoTL is brought to you for free and open access by ISU ReD: Research and eData. It has been accepted for inclusion in Teaching and Learning in Communication Sciences \& Disorders by an authorized editor of ISU ReD: Research and eData. For more information, please contact ISUReD@ilstu.edu. 


\title{
Language, Literacy, and Multiliteracies: Preparing Graduate Students to Provide Language Intervention in the 21st Century
}

\author{
Abstract \\ The concept of multiliteracies and its application in educational settings are described with a specific \\ focus on the potential benefits and challenges in use of this approach with children with a language- \\ based learning disability (LLD). The role of traditional literacy skills within a multiliteracies perspective is \\ examined and the literacy skills required by children when using new modes of communication such as \\ texting are discussed. Finally, the implications for educating prospective speech-language pathologists to \\ provide service in a broader literacy landscape are examined.
}

\section{Keywords}

multiliteracies, literacy, speech-language pathology curricula, communication technology, texting

\section{Cover Page Footnote}

Correspondence regarding this article should be addressed to: Wanda Kent, Department of Special Education, Eastern Michigan University, Ypsilanti, MI 48197. E-mail: wkent2@emich.edu 
The term multiliteracies (New London Group, 1996) has been used to describe forms of literacy, often associated with the use of new technologies, in which traditional linguistic content is embedded in, augmented by, or accompanied by information in various other modalities. Thus, the presentation of information in these new literacies or multiliteracies is typically multimodal (Kress, 2003). Linguistic and visual information, often with links to additional information, found on websites and in social media provide examples of these new literacies as do the changes in spelling, font size, and use of capitalization that may accompany text messages. These new forms of literacy contrast with traditional print literacy in which linguistic information is conveyed by lines of uniform black type printed from left-to-right on a paper page.

Professionals in communication sciences and disorders (CSD) have an inherent interest in literacy as a language-based skill and graduate students in the field receive extensive academic instruction related to language and literacy across the lifespan. However, current curricula focus almost exclusively on traditional perspectives of literacy. The aim of this paper is to examine issues related to the education of future clinicians who will provide speech-language services in the new communication contexts surrounding multiliteracies. It should be noted that, although issues related to multiliteracies warrant consideration in intervention for clients with various communication disorders, the particular focus in this paper is the potential impact of a multiliteracies perspective of literacy on school-age children with a language learning disorder (LLD; Paul \& Norbury, 2012) and considerations for the future clinicians who will provide services to them in schools.

\section{Language and Literacy in CSD Curricula}

Students in graduate programs in CSD complete a comprehensive program of academic coursework related to traditional language and literacy skills in children and adults. Graduate students learn about early language and literacy skills development in children, the role these skills play when children enter school, how to intervene to provide remediation when children fail to develop language and literacy skills as expected, and how to intervene when language and literacy skills are impacted by illness or trauma. Graduate students also learn about later developing language and literacy skills in adults, considerations for intervention when these skills are impacted by illness or trauma, and the effect of language and literacy skills' levels on academic or vocational outcomes.

The weight placed on language and literacy teaching in graduate programs in CSD is not surprising given the extensive research that has documented the relationship between oral language and literacy skills (e.g., Catts, Adlof, \& Weismer, 2006; Hogan, Adlof, \& Alonzo, 2014; Tilstra, McMaster, Van den Broek, Kendeou, \& Rapp, 2009). Indeed, frameworks such as the Simple View of Reading (Gough \& Tunmer, 1986; Hoover \& Gough, 1990) highlight the role of various language skills in reading and the American Speech-Language Hearing Association (ASHA) (2001) issued a position statement that outlined the role of speech-language pathologists with respect to reading and writing in children and adolescents.

Nevertheless, in the sixteen years since the publication of ASHA's position statement, the rapid pace of technological evolution has altered not only the nature and mode of communication, but it has also changed those with whom we communicate. Indeed, the very definition of literacy and 
what it means to be literate has new meaning. The accelerated rate of change in communication within society is challenging our profession not only to define how to address both the oral and written communication needs of clients within new technologies and social settings, but also to examine how best to prepare new practitioners entering the field. In addition to providing graduate students with information about language and literacy, consideration must be given to providing them with tools to also assess and provide intervention for multimodal representations of language and multiliteracies.

\section{The Emergence of Multiliteracies}

Traditionally, the development of reading and writing skills has been one of the primary objectives in education systems in North America. Although the approaches to teaching these skills have varied throughout the generations and although the terminologies have changed, the objective has remained the same: Children must learn to read and write print material. Research in CSD and other fields has examined various aspects of reading including early skills that may facilitate reading development (e.g., Carson, Gillon, \& Boustead, 2013), factors related to reading comprehension (e.g., Hogan, Adlof, \& Alonzo, 2014), and remediation programs for those students whose skills are not developing along the same paths as those of their peers (e.g., Snowling, 2013). Even though new ideas and new programs have emerged, the focus has remained on traditional print literacy skills. Nevertheless, the literacy landscape has changed dramatically in recent decades: Technology has produced smart phones, compact and efficient home computers, the internet, e-mail, and blogs, as well as social media such as Twitter, Snapchat, and Facebook. Using apps such as Viber, Skype, WhatsApp, and Facetime, individuals now have the ability to remain in constant communication, not only with those within their immediate community, but also with individuals around the world.

The concept of literacy has been redefined: It no longer refers to a single skill employed during reading and writing of traditional print media but rather a multitude of skills that are applied in various modalities. In response to these changes in society, education is changing its definition of literacy and the focus has turned to multiliteracies. The New London Group (1996) discussed the increased complexity of meaning conveyed by multiliteracies and described 6 modalities of literacy, each with their own respective grammars: "Linguistic Design, Visual Design, Audio Design, Gestural Design, Spatial Design and Multimodal Design" (p. 25). Within the context of multiliteracies and a multiliteracies curriculum, some or all of these modalities are employed. The last modality, Multimodal Design, creates layers of meaning from the other modalities so that a new meaning is created that goes beyond the meaning conveyed by each of the other modalities alone (New London Group, 1996).

Thus, the use of multiliteracies in the classroom has the potential to enrich the curriculum for most students; however, for those students, who do not have the prerequisite skills necessary for development of traditional literacy skills, a multiliteracies approach to learning may pose different benefits and challenges. One group of students who may have difficulty acquiring traditional literacy skills is that comprised of students with a LLD. 


\section{Literacy and Children with a LLD}

Children with a LLD and Traditional Literacy. Children who have been diagnosed with a LLD exhibit weaknesses in various aspects of oral language and literacy. These difficulties may be manifested in problems in comprehension or production of the structural aspects of language (e.g., syntactic, morphological, or phonological skills), the content of language (e.g., vocabulary and semantic knowledge), or the social use of language (e.g., pragmatic skills) (Paul \& Norbury, 2012). Research has demonstrated that these children are also at risk for difficulties with development of age-appropriate reading, writing, and spelling skills (e.g., Catts, Fey, Tomblin, \& Zhang, 2002). Furthermore, there appears to be a reciprocal relationship between oral language and reading development (ASHA, 2001; Catts et al., 2002).

Children with a LLD in a Multiliteracies Environment. As discussed previously, language and literacy skills today are required not only for traditional pencil-and-paper tasks but also for new forms of communication in which traditional forms of literacy are embedded. Educational institutions are acknowledging these new literacy requirements and changes are now seen beginning with the curricula in the early elementary school years. For example, some jurisdictions include in their language curricula not only oral communication, reading and writing, but also media literacy skills (See Ontario Ministry of Education, 2006). These changes may offer both potential benefits and challenges to children with language-learning disorders.

Possible benefits in a multiliteracies environment. Despite the complexity of a multiliteracies approach to education, there may be some advantages in such an approach for children who have weaknesses in language and literacy skills development. One of the first advantages to such an approach is that multiliteracies can facilitate a shift in focus from disability. Siegel (2006) introduced the term semiotic toolkit to describe the inherent meaning-making skills children possess when they enter the educational system. These skills relate not only to the sign system of print literacy but also sign systems related to visual literacy and technological literacy. From a multiliteracies perspective, the children's skills are assessed with respect to all the tools in the toolkit not only those tools related to specific academic content areas. Through this lens, children with language and traditional literacy weaknesses may demonstrate significant strengths in other new literacies. The children's weaknesses do persist; however, these are no longer viewed in isolation but in relation to children's strengths, affording both the children and those working with them a more balanced impression of their abilities. For graduate student clinicians, this perspective should dovetail with their clinical training which teaches them to evaluate both their client's strengths and weaknesses.

The concept of the semiotic toolkit leads to a second potential benefit of a multiliteracies approach when working with children who have weaknesses in language and literacy. That benefit is derived from the fact that not only do education professionals assess the toolkits of the children, but education professionals must assess the contents of their own toolkits. Within the rubric of a traditional learning model, the knowledge within the classroom rested primarily with the teacher. The teacher transmitted information to children via oral language and print media, and the children absorbed that information (Siegel, 1995). Siegel (1995) indicated that there is some evidence that use of a language-focused model in the classroom is limiting to children and that it reinforces this 'transmission model'. With the rapid pace of technological development, many children in schools 
possess greater technological knowledge than many education professionals. An honest evaluation by education professionals of the contents of their respective toolkits could equalize knowledge between education professionals and children, enabling all children to feel that they are bringing valued skills to the learning environment. Even the most technologically adept graduate student clinicians may find that their school-age clients have a greater and/or more current knowledge of technology than they possess. This offers the opportunity for the client to become the instructor, thereby providing occasions for a variety of authentic language and literacy activities.

Another benefit that may be derived from a multiliteracies approach to education is the advantage afforded by the redundancy and repetition involved in the presentation of a message in a variety of modalities. Children with weaknesses in language and literacy may not receive the same information from an oral or print message as their typically-learning peers. Their vocabulary knowledge may not provide them with the same semantic resources from which to obtain meaning; they may experience difficulty comprehending sentences that contain complex syntactic forms and their decoding and reading comprehension skills may be insufficient to obtain accurate meaning from text (Paul \& Norbury, 2012). When oral and written language in classroom instruction is layered with meaning through the use of other modalities (e.g., visual representations, music, drama, or film), there may be increased opportunities for children with language-based weaknesses to access meaning. Nevertheless, it cannot be assumed that children may be able to access meaning in a given modality independently and, as Westby (2010) cautions, children may also require support in the use of visual representations. Finally, use of electronic text may offer another form of layering of meaning. For example, electronic texts that provide students with hyperlinks to explanations of word and text meanings can provide additional layers of meaning that may support children's text comprehension (RAND Reading Study Group, 2002).

Potential challenges in a multiliteracies environment. Although there may be many potential benefits for children with LLD in use of a multiliteracies curriculum, there are a number of constraining factors that must be considered. The primary concern is that despite their potential literacy strengths in a multiliteracies environment, these children continue to experience difficulty with traditional language-based or literacy-based tasks, and competence in the use of these traditional skills is presupposed by creators of new technologies. Luke (2003) described the skills required for proficiency in computer and internet use: "Consider, for instance, that just to get into any basic computer program requires facility with both print literacy and any number of symbolic languages so that we know where to click in order to move through menued choices" (p. 72).

Luke (2003) emphasized the role of print literacy as one of the foundational literacies in the multiliteracies involved in computer use. Thus, children with weaknesses in use of printed text may not be able to read the information efficiently enough on some websites to accurately follow the site's directions. Furthermore, children with language weaknesses may not have the vocabulary or semantic skills required to interpret meaning. Although these children may access some of the meaning conveyed by website designers, they may not access the full meaning or the most important parts of the meaning.

Another skill required by readers of web-based text is that of discernment. Readers in a multiliteracy environment must be able to sort relevant text from other stimuli (e.g., pop-ups and advertising text on the computer screen) and they must be able to discern fact from opinion. 
Making these judgments may be difficult for children who are not adept at making inferences and comprehending abstract language.

Finally, there may be significant variability in the form of text used with new technologies (e.g., when sending text messages or tweets). Although some users of these technologies may adhere to traditional text forms, many will adopt minimalized text forms and these forms require new skills for both reading and writing. Skill is required when creating messages in these formats so that the intended message is conveyed within the constraints imposed by the medium (e.g., character limits in Twitter).

Specific considerations relating to texting activity. Studies of the characteristics of texting activity by school-age children with various language impairments provide examples of the new communication demands from this one frequently used mode of communication. Recent research has examined the effects of texting on language and literacy skills as well as texting abilities in both typically developing children and children with language or learning differences (e.g., Blom, van Dijk, Vasic, van Witteloostuijn, \& Avrutin, 2017; Wood, Jackson, Hart, Plester \& Wilde, 2011). Although some have questioned potential negative impacts of text language on traditional language skill development, this negative impact has not been supported by recent research (e.g., Wood et al., 2011).

Nevertheless, when Blom and colleagues (2017) examined the use of texting and textese in 55 children (ages 10 to 13) with typically developing language skills and 15 children with specific language impairment (SLI), both potential benefit and challenge in the use of texting was reported for the children with SLI. The authors found no difference in the text message length of children with typically developing skills and children with SLI; however, they did report that the children with SLI used fewer textisms (alternative word spellings) than the children with typically developing language skills (Blom et al., 2017). They also reported that the children with typically developing language skills omitted more words when texting than in speech whereas, the children with SLI produced a similar number of omissions in text and speech (Blom et al., 2017). The authors noted that this result may be reflective of failure on the part of the children with SLI to distinguish between texting and speech registers. Nevertheless, the authors observed that texting appeared to enable the children with SLI to meet socio-emotional needs, such as, expressing ideas/feelings that they may not have been able to express otherwise (Blom et al., 2017).

Although, Blom and colleagues (2017) identified a possible social language benefit from texting for children with SLI, skilled texting demands skilled language and literacy use. Research with school-age children has reported that textism use may be positively related to phonological awareness skills (Coe \& Oakhill, 2011; Plester, Wood \& Joshi, 2009), verbal reasoning skills (Plester, Wood, \& Bell, 2008), writing skills (Plester et al., 2008), word reading skills (Plester et al., 2009), vocabulary skills (Plester et al., 2009), and spelling skills (Plester et al., 2008; Wood, Meachem, Bowyer, Jackson, Tarczynski-Bowles, \& Plester, 2011). Additionally, texting skills (i.e., speed and accuracy of textese reading) were positively related to literacy skills (Kemp \& Bushnell, 2011). Finally, Plester and Wood (2009) observed that several forms of textisms demand strong language and literacy skills, particularly in the areas of phonological awareness and alphabet knowledge, and noted that text messages that are produced phonetically demand strong phonological awareness skills on the part of both sender and receiver. 


\section{Preparing Graduate Students to Provide Speech-Language Intervention in a Multiliteracies Environment}

Graduate students in CSD are uniquely situated to help their school-age clients navigate this new literacy landscape. The majority of current graduate students have not known a world without digital technology; however, the challenge is to enable graduate students to develop critical thinking skills and flexible thinking skills that will enable them to view the communication landscape from a broad perspective. They must be able to take the foundational knowledge they have acquired about oral language and literacy, and apply this knowledge within new communication settings and with new communication tools. They must also be able to identify children's needs in all communicative contexts and help children develop the skills and/or strategies required to meet those needs.

Increasing Graduate Students' Awareness of the New Communication Landscape. Although graduate students acquire knowledge about traditional models of language and literacy skills in their academic courses, language and literacy skills today are required for new forms of communication in which the traditional skills are embedded and supply just one component of the message. Graduate students must be challenged to extrapolate their academic learning about language and literacy to the new communication demands and technologies encountered by children both inside and outside of the classroom. It may be appropriate across all academic courses in CSD to encourage graduate students to examine: 1) what it means to communicate; 2) how individuals communicate; 3) what skills are required to communicate effectively; 4) the meaning of literacy; and 5) what it means to be literate. This discussion could then lead to a consideration of multiliteracies and communication with new technology as well as consideration of the requisite skills required for these forms of communication.

Helping Graduate Students Recognize New Communication Demands. Although most graduate students are experienced users of new technologies, they may not recognize the language and communication demands involved in their use. However, just as they have been encouraged to peel away the layers of traditional classroom academic tasks to identify the language and literacy demands at each layer, today's graduate students must do the same to identify the language and literacy skills required by new communication contexts and technologies in the classroom and beyond. Moreover, given that new modes of communication (i.e., texting) are often the preferred mode of communication, particularly among the young, it is appropriate that graduate students in CSD learn to identify the task requirements of these new modalities and tailor their intervention to support children's language and literacy skills in these authentic communication activities.

Some fairly straightforward changes to graduate curricula could be implemented to facilitate this learning by graduate students in CSD. For example, in courses about school-age language and literacy disorders, a discussion of current research could highlight the potential benefits and challenges for children with LLD when they engage in new literacy activities such as texting. This discussion could then be extended to examine the various forms of literacy or multiliteracies that are required of children in the classroom, the home, and various social/recreational activities. Graduate students could brainstorm ways to tailor their assessments to include information about children's skills in these authentic literacy contexts and then to generate appropriate language goals 
that would support both traditional and new forms of literacy. For example, the relationship between the development of phonological awareness skills and traditional literacy skills is well established (e.g., Carson et al., 2013), and a relationship between phonological awareness skills and texting skills has been noted in the sample of research discussed earlier in this paper (See Coe \& Oakhill, 2011; Plester \& Wood, 2009). This is one area in which the overlap of skills between traditional and new literacies may be more readily apparent for graduate students.

Helping Graduate Students Apply Traditional Principles of Practice to New Literacies. There are various ways in which a multiliteracies approach can be incorporated into speech-language intervention. Firstly, a multiliteracies perspective may be adopted as the framework for intervention. This may begin at the assessment and data gathering stage. Graduate students in CSD could be encouraged to seek information regarding the type, amount, and quality of children's use of various technologies as appropriate for children's ages, stages of development, and abilities. For children with LLD, the effect of their language skills on their ability to engage with new forms of literacy could be examined.

At the intervention stage, engagement with new forms of literacy may be appropriate in intervention activities. For example, Malani (2013) indicated that increases in student motivation and students' perceptions of themselves as readers are possible benefits of use of digital texts in speech-language intervention. However, appropriate planning and introduction of the text must be completed before using multimedia, such as videos, to support comprehension so that the new media do not distract from the content (Malani, 2013). Additionally, use of a multiliteracies approach may be particularly appropriate in work with individuals from specific cultural groups. For example, Inglebret and colleagues (2011) stated that many facets of a multiliteracies perspective parallel traditional cultural practices in Indigenous communities. Finally, Westby (2010) described a multiliteracies approach to intervention that was implemented with two adolescents with language impairment. The intervention plan was constructed as a four-component multiliteracies map that outlined skills to be learned and activities to be used to develop those skills within a multiliteracies framework. Westby (2010) stated that use of the multiliteracies map to frame intervention helps support student communication skills development (e.g., social and academic language skills) “...in a way that prepares students for the literacy demands of the $21^{\text {st }}$ century" (p. 70).

Secondly, intervention employing new literacies and new technologies may be used to address traditional language and literacy goals as it has been suggested that skills related to new literacies may support growth in other language skills. Plester and Wood (2009) described the potential benefits to traditional literacy skills associated with children's texting activity and stated that "the sophisticated manipulation of language as achieved through functional practice and active experience gained through texting, may provide a transferable skill concerning the ready application of enhanced phonological knowledge and thus aid standard literacy development" (p. 1115). Furthermore, the use of mobile devices has been shown to have an intervention effect in various types of academic interventions in educational settings (Sung, Chang, \& Liu, 2016).

Finally, specific skills required for new literacies may be targeted directly in intervention. For example, Plester and colleagues (2008) noted that texting requires awareness of the difference in register between Standard English and text language; however, as noted previously, Blom and 
colleagues (2017) questioned whether children with SLI distinguish between Standard English and texting registers. For some children for whom texting is an important part of their social activity, it may be appropriate to use texting as one context in which to target pragmatics and appropriate use of register.

\section{Conclusions}

Multiliteracies curricula and multiliteracies research hold great promise; however, they also hold new challenges for future clinicians and those who educate them. Change is occurring in elementary and high school classrooms; however, modifications are also required at the curricular levels in higher education in order to prepare clinicians who are equipped to adapt their practices in schools. At this point in educational history, these alterations are particularly relevant. Recent technological, economic and social changes have combined to create an atmosphere in which multiliteracies no longer exist only in research, but are a reality of everyday life. If one of the main purposes of education is to provide tools to enable children to function as capable and enlightened citizens in their world, then education must expose them to a variety of literacies and instruct them in their use. Nevertheless, traditional literacy remains a foundational component of these multiliteracies.

Given the pace of technological change in society today, it is more important than ever that graduate students in CSD have a solid knowledge base regarding oral language and its relationship to 'traditional' literacy, not only to address children's immediate needs within these areas, but also to anticipate how children may require these communication skills in novel settings. They must be prepared to be flexible, adaptable, critical thinkers and astute clinicians who recognize the language demands of the tasks required of children in schools or social/recreational settings, and who are prepared to assist children on their caseloads to develop the skills or strategies to meet those demands. Mills (2009) stated, "The multiliteracies argument has awakened literacy educators to recognise that the skills required to communicate effectively in society are constantly changing" (p. 108). Thus, graduate students in CSD and those who educate them must be prepared to stay abreast of the technological times and adapt their practices accordingly.

\section{References}

American Speech-Language-Hearing Association. (2001). Roles and responsibilities of speechlanguage pathologists with respect to reading and writing in children and adolescents [Position Statement]. Retrieved from www.asha.org/policy.

Blom, E., van Dijk, C., Vasic, N., van Witteloostuijn, M., \& Avrutin, S. (2017). Textese and use of texting by children with typical language development and specific language impairment. Computers in Human Behavior, 66, 42-51.

Carson, K. L., Gillon, G. T., \& Boustead, T. M. (2013). Classroom phonological awareness instruction and literacy outcomes in the first year of school. Language, Speech, and Hearing Services in Schools, 44, 147-160. doi:10.1044/0161-1461(2012/11-0061)

Catts, H. W., Adlof, S. M., \& Weismer, S. E. (2006). Language deficits in poor comprehenders: A case for the simple view of reading. Journal of Speech, Language, and Hearing Research, 49, 278-293. 
Catts, H. W., Fey, M. E., Tomblin, J. B., \& Zhang, X. (2002). A longitudinal investigation of reading outcomes in children with language impairments. Journal of Speech, Language, and Hearing Research, 45, 1142-1157.

Coe, J. E. L., \& Oakhill, J. V. (2011). TxtN is ez $\mathrm{f} \mathrm{u} \mathrm{no} \mathrm{h2} \mathrm{rd:} \mathrm{The} \mathrm{relation} \mathrm{between} \mathrm{reading} \mathrm{ability}$ and text-messaging behaviour. Journal of Computer Assisted Learning, 27, 4-17.

Gough, P. B., \& Tunmer, W. E. (1986). Decoding, reading, and reading disability. Remedial and Special Education, 7, 6-10. doi: 10.1177/074193258600700104

Hogan, T. P., Adlof, S. M., \& Alonzo, C. N. (2014). On the importance of listening comprehension. International Journal of Speech-Language Pathology, 16(3), 199-207. doi: 10.3109/17549507.2014.904441

Hoover, W. A., \& Gough, P. B. (1990). The simple view of reading. Reading and Writing: An Interdisciplinary Journal, 2, 127-160.

Inglebret, E., Pavel, D. M., \& Pavel, K. (2011). Multiliteracies: An approach for framing service delivery with indigenous children. Downloaded from http://sig14perspectives.pubs.asha.org.

Kemp, N., \& Bushnell, C. (2011). Children's text messaging: Abbreviations, input methods and links with literacy. Journal of Computer Assisted Learning, 27, 18-27.

Kress, G. (2003). Design and transformation: New theories of meaning. In B. Cope \& M. Kalantzis (Eds.), Multiliteracies: Literacy learning and the design of social futures (pp. 153-161). New York: Routledge.

Luke, C. (2003). Cyber-schooling and technological change: Multiliteracies for new times. In B. Cope \& M. Kalantzis (Eds.), Multiliteracies: Literacy learning and the design of social futures (pp. 69-91). New York: Routledge.

Malani, M. (2013). Entering the digital literacy era: Considerations for digital texts in intervention. Retrieved from: http://sig16perspectives.pubs.asha.org.

Mills, K. A. (2009). Multiliteracies: Interrogating competing discourses. Language and Education, 23(2), 103-116. doi: 10.1080/09500780802152762

New London Group. (1996). A pedagogy of multiliteracies: Designing social futures. Harvard Educational Review, 66, 60-92.

Ontario Ministry of Education. (2006). The Ontario Curriculum, Grades 1-8: Language, 2006 (revised). Retrieved from http://www.edu.gov.on.ca/eng/curriculum/elementary/language18currb.pdf

Paul, R., \& Norbury, C. F. (2012). Language disorders from infancy through adolescence: Listening, speaking, reading, writing, and communicating (4th ed.). St. Louis, MO: Elsevier.

Plester, B., \& Wood, C. (2009). Exploring relationships between traditional and new media literacies: British preteen texters at school. Journal of Computer-Mediated Communication, 14, 1108-1129. doi:10.1111/j.1083-6101.2009.01483.x

Plester, B., Wood, C., \& Bell, V. (2008). Txt msg n school literacy: Does texting and knowledge of text abbreviations adversely affect children's literacy attainment? Literacy, 42(3), 137144.

Plester, B., Wood, C., \& Joshi, P. (2009). Exploring the relationship between children's knowledge of text message abbreviations and school literacy outcomes. British Journal of Developmental Psychology, 27, 145-161.

RAND Reading Study Group. (2002). Reading for understanding: Toward an $R \&$ D program in reading comprehension. Washington, DC: RAND Education. 
Siegel, M. (1995). More than words: The generative power of transmediation. Canadian Journal of Education, 20 (4), 455-475.

Siegel, M. (2006). Rereading the signs: Multimodal transformations in the field of literacy education. Language Arts, 84(1), 65-77.

Snowling, M. (2013). Early identification and interventions for dyslexia: A contemporary view. Journal of Research in Special Educational Needs, 13(1), 7-14. doi: 101111/j.14713802.2012.01262.x

Sung, Y., Chang, K., \& Liu, T. (2016). The effects of integrating mobile devices with teaching and learning on students' learning performance: A meta-analysis and research synthesis. Computers \& Education, 94, 252-275.

Tilstra, J., McMaster, K., Van den Broek, P., Kendeou, P., \& Rapp, D. (2009). Simple but complex: Components of the simple view of reading across grade levels. Journal of Research in Reading, (32)4, 383-401. doi: 10.1111/j.1467-9817.2009.01401.x

Westby, C. (2010). Multiliteracies: The changing world of communication. Topics in Language Disorders, 30(1), 64-71.

Wood, C., Jackson, E., Hart, L., Plester, B., \& Wilde, L. (2011). The effect of text messaging on 9- and 10-year-old children's reading, spelling, and phonological processing skills. Journal of Computer Assisted Learning, 27, 28-36.

Wood, C., Meachem, S., Bowyer, S., Jackson, E., Tarczynski-Bowles, L., \& Plester, B. (2011). A longitudinal study of children's text messaging and literacy development. British Journal of Psychology, 102, 431-442. 